\section{The Effect of Time of Sweetpotato Whitefly Infestation on Plant Nutrition and Development of Tomato Irregular Ripening Disorder}

\author{
Cindy L. McKenzie ${ }^{1}$ and Joseph P. Albano
}

Additional IndeX words. Bemisia argentifolii, Bemisia tabaci B biotype, silverleaf

Summary. Tomato irregular ripening (TIR) disorder is associated with sweetpotato whitefly (Bemisia tabaci) biotype B feeding and is characterized by incomplete ripening of longitudinal sections of fruit. Our objective was to determine the effect of time of sweetpotato whitefly infestation on plant nutrition and the development of TIR disorder. Healthy tomato plants (Solanum lycopersicum 'Florida Lanai') were introduced to sweetpotato whitefly infestations at different developmental stages of plant growth: 1) five to seven true leaves, 2) flower, 3) green fruit, and 4) breaking red fruit and were compared with noninfested control plants of the same age. Plants were fertilized every 7 to 14 days. Plant nutrition was monitored over time between the noninfested control and the longest infestation interval (five to seven true leaves) and between all infestation intervals at harvest. Sweetpotato whitefly (egg, nymph, and adult) and plant parameters (height, canopy diameter, number of leaves, flowers, and fruit per plant) were taken every 7 to 14 days after sweetpotato whitefly infestation. Almost all of the fruit $(99 \%)$ produced by tomato plants infested with sweetpotato whitefly at stages 1 and 2 (78 and 56 days of sweetpotato whitefly exposure, respectively) developed TIR with fruit exhibiting internal and external symptoms. Plants infested at stage 3 (35 days of sweetpotato whitefly exposure) had $79 \%$ to $80 \%$ of the fruit develop TIR. Surprisingly, $58 \%$ of fruit from plants infested at stage 4 ( 14 days of sweetpotato whitefly exposure) also developed the disorder, indicating that tomatoes may need to be protected from sweetpotato whitefly until harvest to avoid this disorder. Seed germination was unaffected by TIR. Plants infested with sweetpotato whitefly had mean foliar levels of calcium, copper, iron, phosphorous, potassium, magnesium, manganese, and zinc that were greater than in noninfested control plants at final harvest for both studies, regardless of time of infestation.

$\mathrm{T}$ he sweetpotato whitefly has been reported in Florida since the late 1800 s, but has only been considered a pest since 1986 when poinsettia (Euphorbia pulcherrima) growers began experiencing crop-damaging infestations (Hamon and Salguero, 1987; Hoelmer et al., 1991). Before 1986, the sweetpotato whitefly was thought to be virtually the same everywhere it occurred throughout the tropics, subtropics, and mild temperate regions of the world. By Fall 1987, sweetpotato whitefly had moved from ornamental crops to eggplant (Solanum melongena) and cucurbits (Cuburbitaceae)

U.S. Department of Agriculture, Agricultural Research Service, U.S. Horticultural Research Laboratory, 2001 South Rock Road, Fort Pierce, FL 34945

We thank Gary Ouellette, Erin Walker, Jordan Spaw, Donald Hamm, Ryan Hamm, and Chris Lasser (USDA, ARS, U.S. Horticultural Research Laboratory, Fort Pierce, FL) for their dedicated technical assistance. We wish to dedicate this paper to the memory of Donald "Andy" Hamm.

${ }^{1}$ Corresponding author. E-mail: cindy.mckenzie@ars. usda.gov. known as biotype $\mathrm{B}$ to distinguish it from the indigenous biotype A. The Abiotype had been relatively benign in Florida, but caused serious losses in California and Arizona as a cotton pest and a vector of a crinivirus that causes lettuce infectious yellows disorder in lettuce (Lactuca sativa) and melons (Cucumis melo) (Duffus, 1995). Bean golden mosaic, tomato mottle, and tomato yellow leaf curl viruses have all appeared for the first time in Florida since the introduction of biotype B (Blair et al., 1995; Kring et al., 1991). Biotype B was described in 1994, although not universally accepted as a new species, Bemisia argentifolii, or silverleaf whitefly (Bellows et al., 1994). Species status was conferred on the basis of biological differences such as failure to produce hybrids with biotype A whiteflies in the laboratory, as well as the ability to cause physiological disorders such as squash silverleaf disorder (Perring et al., 1993).

Sweetpotato whitefly biotype B is also associated with the appearance of a new crop plant disorder in tomato termed irregular ripening (McAuslane, 2007; Schuster et al., 1990). Symptoms of this disorder do not appear on tomato foliage where whitefly feed, but appear as an uneven tomato fruit color development during ripening. The disorder is characterized externally by incomplete reddening of the fruit exhibited by longitudinal white or yellow streaks that typically start as a star at the blossom end of the fruit that can become more pronounced with the points radiating up the fruit. Color often develops along locule walls with intermediate areas remaining green or yellow, producing a star-burst appearance. Internally, fruit exhibit white or yellow tissues.

The mechanism(s) of symptom development and the physiological bases of tomato irregular ripening disorder are not completely understood, 
although altered gibberellin metabolism (Hanif-Khan et al., 1997) and suppression of ethylene biosynthesis in tomato fruit (McCollum et al., 2004) as a result of sweetpotato whitefly feeding have been reported. Fruit firmness is also affected by sweetpotato whitefly feeding, and tomatoes do not soften to the same extent as do fruit from plants free of sweetpotato whitefly (McCollum et al., 2004). The severity of the disorder is thought to be density dependent (Schuster, 2001; Schuster et al., 1990), and apparently very low sweetpotato whitefly numbers can induce the disorder (Schuster, 2002). The most common commercially grown tomato cultivars in Florida (Powell and Stoffella, 1995a) as well as many cherry tomato cultivars (Hanif-Khan et al., 1998) were found to have no significant tolerance to tomato irregular ripening. Culling based on external symptoms is of limited value due to fruit not exhibiting external symptoms, although they may still have a high incidence of internal symptoms (Powell and Stofella, 1995b). Cultural practices such as reflective aluminum mulch (Powell and Stofella, 1993) or cold storage before ripening (Powell and Stofella, 1995b) have not significantly reduced the incidence of tomato irregular ripening; however, several insecticides or insecticide combinations have been shown to reduce the severity of the disorder by reducing sweetpotato whitefly populations (Powell and Stofella, 1998; Schuster, 2002; Schuster et al., 1989a, 1989b)

Plant nutrition may also play a key role in the tomato ripening process (Delahuat and Stevenson, 2004). Picha and Hall (1981) reported that $\mathrm{K}$ deficiency and certain environmental conditions such as temperature and humidity have been associated with the development of external blotchy ripening and internal white tissue in fresh-market tomatoes. Blotchy ripening is a physiological disorder that is exasperated by cool, short days, drought conditions, and high tissue nitrogen $(\mathrm{N})$ levels or inadequate levels of other nutrients (Delahunt and Stevenson, 2004; Olson, 2004).

In the present study, our objective was to determine the effect of time of sweetpotato whitefly infestation on plant growth and nutrition and the development of tomato irregular ripening disorder. We introduced healthy tomato plants to sweetpotato whitefly infestations at different physiological stages of plant growth (noninfested control, five to seven true leaves, flower, green fruit, and breaking red fruit). Foliar nutrient levels, and plant and sweetpotato whitefly growth parameters were monitored over time, and fruit was rated for tomato irregular ripening disorder at final harvest.

\section{Materials and methods}

ENVIRONMENTAL CONDITIONS. 'Florida Lanai' dwarf cherry tomato seedlings were transplanted in a peatbased potting medium (Pro-Mix BX; Premier Horticulture, Quakertown, PA) in 1-gal containers in walk-in growth chambers [Environmental Growth Chambers (EGC), Chagrin Falls, $\mathrm{OH}$ ]. Growth chambers were programmed to maintain day/night temperatures and relative humidity at 28 to $20{ }^{\circ} \mathrm{C}$ and $40 \%$ to $80 \%$, respectively, with a 12 -h photoperiod. To simulate morning, midday, and evening incident solar radiation during a photoperiod, illumination began with the activation of two light banks on one side of the growth chambers during the first $2 \mathrm{~h}$ (dawn), followed by illumination from all light banks for the next $8 \mathrm{~h}$, and ending with illumination with two light banks on the opposite side of the growth chamber for the final $2 \mathrm{~h}$ (dusk) of the $12-\mathrm{h}$ photoperiod. The radiation source was a combination of $400-\mathrm{W}$ highintensity discharge (HID) metal halide (Sylvania M400/U; OSRAM Sylvania, Danvers, MA) and highpressure sodium lamps (Sylvania LU400) (one set of each light source composed a light bank with 16 light banks per growth chamber; eight banks on each side of the growth chamber). The environmental conditions were the same for Expts. 1 and 2 , and both experiments were conducted for $126 \mathrm{~d}$.

Application of water and FERTILIZER. Applications (500-1000 $\mathrm{mL}$ ) of water or soluble fertilizer were performed as sub- and surfaceirrigations, respectively. For water irrigations, containers were placed in clear vinyl saucers that were 8 inches in diameter and 3 inches tall (about $800 \mathrm{~mL}$ capacity) with application made directly to the saucer until the total application volume was made. For application of fertilizer solutions, containers were removed from saucers and application was made directly to the medium surface. Containers were returned to saucers only after leaching had ceased (i.e., containers were fully drained after $15 \mathrm{~min}$ ). Plants were fertilized with a $20 \mathrm{~N}-$ 8.3P-16.6K water-soluble fertilizer (Peter's Professional 20-10-20 Florida Special; Scotts, Marysville, $\mathrm{OH}$ ) at the rate of $200 \mathrm{mg} \cdot \mathrm{L}^{-1}$ nitrogen $(\mathrm{N})$. Fertilizer solutions were applied at 7to 14-d intervals with plants in Expts. 1 and 2 being fertilized on average every 7 and $10 \mathrm{~d}$, respectively, over the course of each study. In Expts. 1 and 2 , the total volume of fertilizer applied per plant was $8.4 \mathrm{~L}$ made in 11 applications and $5.5 \mathrm{~L}$ made in seven applications, respectively, and the total volume of water applied per plant was $32.8 \mathrm{~L}$ made in 39 applications and $33.5 \mathrm{~L}$ made in 39 applications, respectively. Fertilizer was prepared (i.e., diluted to application $\mathrm{N}$ rate) with a tap water source available within the sweetpotato whitefly-infested and noninfested (control) growth chambers, and this same tap water source was used for irrigations.

Foliar NUTRIENT ANALYSis. Foliar nutrient levels were determined between plants infested at the five to seven true leaves (longest infestation) stage and noninfested control plants at each infestation interval and between each infestation interval at harvest. At each harvest, leaf tissue was washed for 10 to $15 \mathrm{~s}$ each in distilled-deionized water (DDI), detergent/acid solution, and three additional DDI rinses as described previously (Albano and Miller, 2003). Leaf tissue was then dried at $70{ }^{\circ} \mathrm{C}$ to a constant weight and was milled to pass a 20-mesh screen. Concentrations of boron (B), calcium (Ca), copper $(\mathrm{Cu})$, iron $(\mathrm{Fe})$, potassium $(\mathrm{K})$, magnesium $(\mathrm{Mg})$, manganese $(\mathrm{Mn})$, molybdenum (Mo), phosphorus (P), and zinc $(\mathrm{Zn})$ were determined by inductively coupled plasma-optical emission spectroscopy (ICP-OES; Intrepid; ThermoScientific, Waltham, MA) according to U.S. Environmental Protection Agency (USEPA) Method 6010B (1997a) following microwave-assisted acid digestion according to USEPA Method 3052 (1997b) modified as follows: plant tissue $(500 \mathrm{mg})$ was digested in $10 \mathrm{~mL}$ of concentrated $(15.8 \mathrm{~N})$, trace-metal grade nitric acid $\left(\mathrm{HNO}_{3}\right)$ 
for $10 \mathrm{~min}$ at $170{ }^{\circ} \mathrm{C}$ and $300 \mathrm{psi}$ (internal digestion-vessel conditions). Digestates were brought to volume $(100 \mathrm{~mL})$ with DDI water and were then gravity filtered (Whatman 54l; Whatman, Maidstone, UK) before analysis. Total foliar $\mathrm{N}$ was performed on the dried, milled leaf tissue by pyrolysis-gas chromatography (model NC 2100; CE Elantech, Lakewood, $\mathrm{NJ})$.

INSECT SOURCE. Adult male and female $B$. tabaci biotype $B$ were obtained from a laboratory colony maintained at the U.S. Horticultural Research Laboratory at Fort Pierce, FL. All stages of sweetpotato whitefly had been maintained on 'Florida Lanai' dwarf cherry tomato since 1996. Colonies were housed in large screened Plexiglas cages located in airconditioned greenhouses with ambient light and humidity. Annual average day and night temperatures fluctuated between 29.4 and $26.7^{\circ} \mathrm{C}$, respectively. Whitefly biotyping was based on mitochondrial DNA markers developed by Frohlich et al. (1999) and sequencing of polymerase chain reaction (PCR) tests.

InSECT TREATMENT. Thirty 'Florida Lanai' dwarf cherry tomato plants were infested with five adult whiteflies per entire leaf (not individual leaflet) in EGC at the five to seven true leaves of growth stage and this inoculation served as the infestation source for the rest of the treatments. Control plants were kept in a separate EGC with the same exact environmental conditions. Plants were subjected to sweetpotato whitefly infestation at different stages of plant development by transferring plants from the control to the infested EGC, after the initial infestation (i.e., five to seven true leaves), at flower, green fruit, and breaking red fruit stage. Plants from the control chamber were placed between infested plants, which were gently agitated so that whiteflies would immediately begin to infest the newly introduced plants. Each infestation time had seven and ten plant replicates for Expts. 1 and 2, respectively.

INSECT AND PLANT PARAMETER MEASUREMENTS. The number of immature sweetpotato whiteflies (eggs, and small and large nymphs) was assessed weekly after sweetpotato whitefly infestation on leaf discs taken between the leaf midveins. Small nymphs included first and second instars and large nymphs included third and fourth instars. Leaf discs were taken randomly from leaflets from the upper, middle, and lower canopy of each plant replicate $(\mathrm{n}=21$ for Expt. 1 and $n=30$ for Expt. 2). Each leaf disc measured $50 \mathrm{~mm}^{2}$ and was stored in ethanol until processing under the microscope. The total number of adult whiteflies was counted from individual tomato leaflets. Leaflets $(\mathrm{n}=100)$ were randomly sampled from the upper, middle, and lower canopy of each plant replicate, nondestructively, by turning the leaflet over.

Tomato plants from the noninfested control plants and plants infested with sweetpotato whitefly at the five to seven true leaves stage were sampled every 10 to $14 \mathrm{~d}$ for height, measured from substrate surface to plant canopy top; canopy diameter, measured at the widest point of the canopy; and number of leaves, flowers, and fruit per plant after sweetpotato whitefly infestation. Flowers were tagged at dehiscence so that fruit of the same age could be compared between treatments at harvest. All plants from each sweetpotato whitefly infestation interval were destructively harvested $14 \mathrm{~d}$ after the last sweetpotato whitefly infestation. Plant parameters were taken and fruit was rated for tomato irregular ripening disorder. Individual fruit was first rated externally for symptoms (pronounced star radiating up the fruit) and were then sliced equatorially and rated internally for symptoms (white tissue). Fruit exhibiting tomato irregular ripening symptoms were rated positive for having the disorder. Seeds were harvested from fruit representing early, middle, and late dehiscence from three to four plants from each treatment and were subsequently sown in 200-cell trays in Fafard Germinating Mix (Conrad Fafard, Agawam, MA) to determine if germination was affected by this disorder.

Statistics. Data were analyzed by the General Linear Models (GLM) procedure of SAS (version 9.1; SAS Institute, Cary, NC), and differences among treatment means were determined by Ryan-Einot-Gabriel-Welsch multiple-range test (REGWQ) at $\alpha=$ 0.05 for sweetpotato whitefly and plant parameter (i.e., height, canopy diameter, number of leaves, flowers, and fruit per plant) data and by
Tukey's honestly significant difference (HSD) test at $P<0.05$ for foliar nutrient data using SAS.

\section{Results and discussion}

Nutrient profiles at EACH STAGE OF GROWTH AND FINAL HARVEST. Experiments 1 and 2 were significantly different for foliar nutrient levels at each harvest time point and at final harvest, and therefore were statistically analyzed and reported separately. The only significant treatment effect overtime was for $\mathrm{N}$ in Expt. 1 where foliar $\mathrm{N}$ levels were significantly higher $(P<0.001)$ in sweetpotato whitefly-infested plants (Fig. 1). This observation was consistent with a previous study where fertilizer was applied weekly at the same $\mathrm{N}$ rate as applied in the current study, under identical environmental conditions, using the same cultivar, under similar sweetpotato whitefly pressure where tomato plants were also infested at the five to seven true leaves stage (McKenzie et al., 2005a). In the previous study, the objective was to study tomato gene expression in response to sweetpotato whitefly feeding using microarray technology.

Foliar nutrient levels related to the time of sweetpotato whitefly infestation at final harvest are presented in Table 1. In Expt. 2, sweetpotato whitefly-infested plants had significantly higher foliar levels of $\mathrm{B}, \mathrm{Ca}$, $\mathrm{Cu}, \mathrm{Fe}, \mathrm{K}, \mathrm{Mg}, \mathrm{Mn}, \mathrm{Mo}, \mathrm{P}$, and $\mathrm{Zn}$ than plants that were never exposed

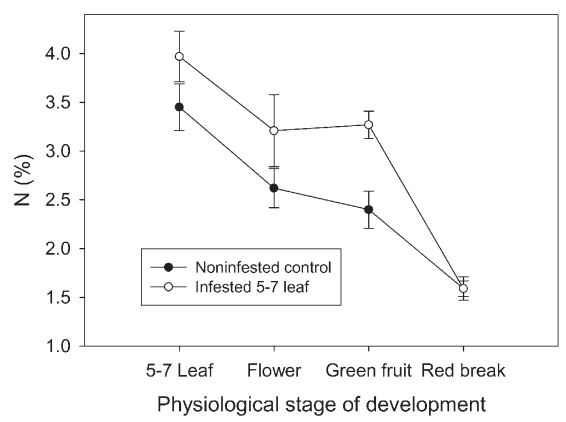

Fig. 1. Foliar nitrogen (N) levels (\%) for 'Florida Lanai' tomato plants in Expt. 1 infested $(O$, infested five to seven true leaves) or noninfested $(\bullet$, noninfested control) at five to seven true leaves of growth (5-7 leaf) with sweetpotato whitefly. Leaves were harvested for $\mathbf{N}$ determination at the physiological stages of growth: 5-7 leaf, flower, green fruit, and red breaking fruit. Vertical bars represent SE of the mean $\left(1 \%=10 \mathrm{mg} \cdot \mathrm{g}^{-1}\right)$. 


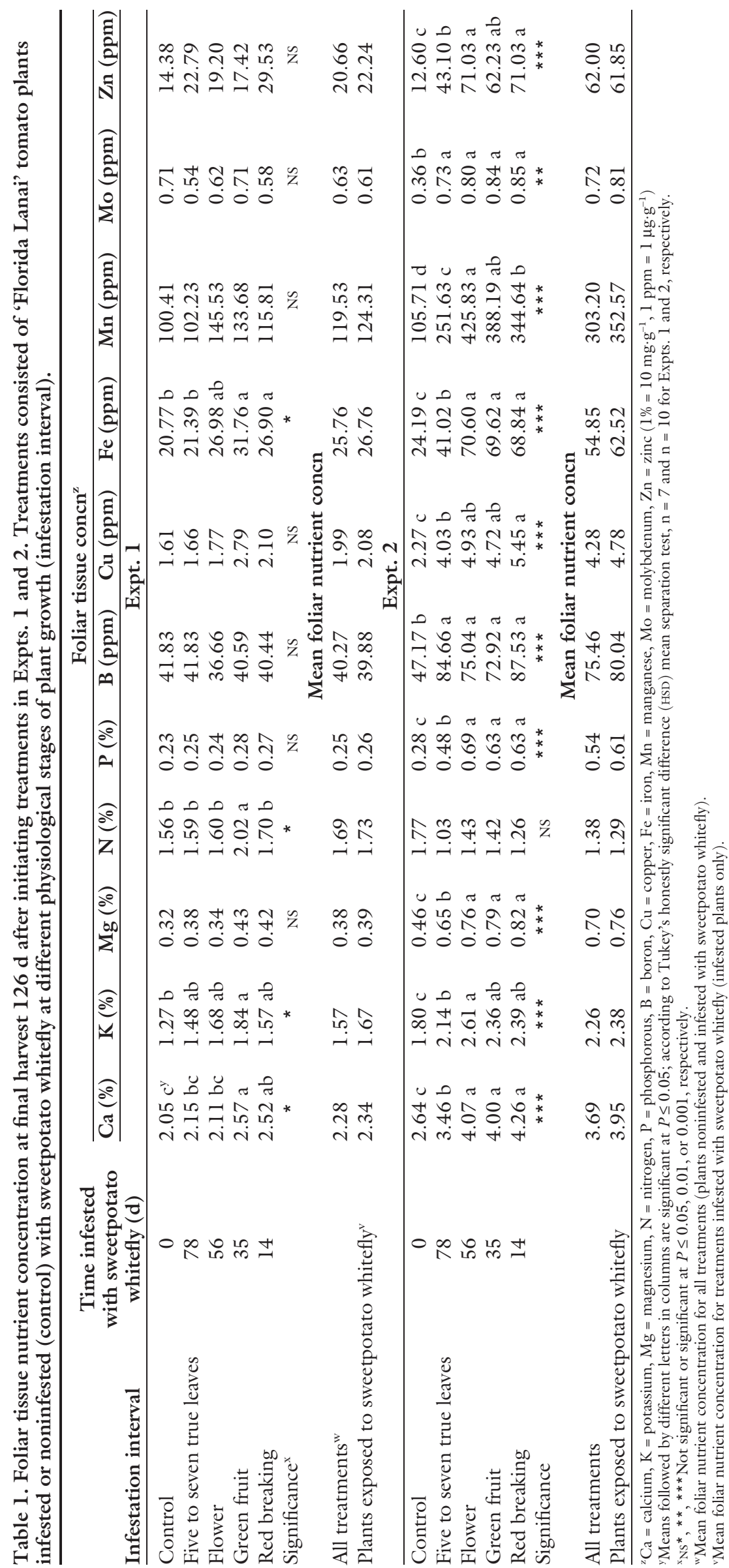


to the pest (i.e., control). In general, compared with commercial tomato cultivars, foliar nutrient levels for tomato plants in these studies at time of flowering were considered "sufficient" for normal plant growth and fruit production (data not presented; Hochmuth et al., 1999).

InSeCt PARAMETERs. Population trends for all stages of sweetpotato whitefly were not significant for experiment and therefore data were combined (Fig. 2). Significant differences were observed between the noninfested control and all sweetpotato whitefly stages evaluated for each date sampled. Populations increased slowly at first, and then doubled after one generation (about $21 \mathrm{~d}$ ) (NavaCamberos et al., 2001) and reached exponential growth with the third generation. Infestation intervals corresponded to sweetpotato whitefly generation time with the exception of the red breaking fruit stage, which had a shorter infestation time of $14 \mathrm{~d}$.

Plant parameters, harvest, FRUIT RATINGS, AND SEED GERMINATION. Within experiments, there were no significant differences over time for number of leaves, plant height, and canopy diameter between the noninfested control plants and plants infested with sweetpotato whitefly at the five to seven true leaves of growth stage (the longest infestation treatment); there were, however, significant differences between experiments with Expt. 1 producing plants that were significantly taller, wider, and with more leaves (Fig. 3). This could be due to more fertilizer (about 33\%) being applied in Expt. I than in Expt. 2. Similarly, plants infested with sweetpotato whitefly at the five to seven true leaves of growth stage in Expt. 1 produced significantly more flowers and fruit compared with the noninfested control plants over time (Fig. 4). In contrast, in Expt. 2, there were no significant differences in number of flowers per plant; however, the noninfested control plants produced significantly more fruit (Fig. 4).

'Florida Lanai' is an inbred cultivar (Augustine et al., 1981). In this study, fruit produced 39 to 55 seeds per plant with a germination rate that ranged from $82 \%$ to $96 \%$ (data not shown). The total number of seeds per fruit $(F=1.64 ; \mathrm{df}=4,28 ; P<$ $0.1914)$ and the germination rates $(F=1.40 ; \mathrm{df}=4,28 ; P<0.2600)$
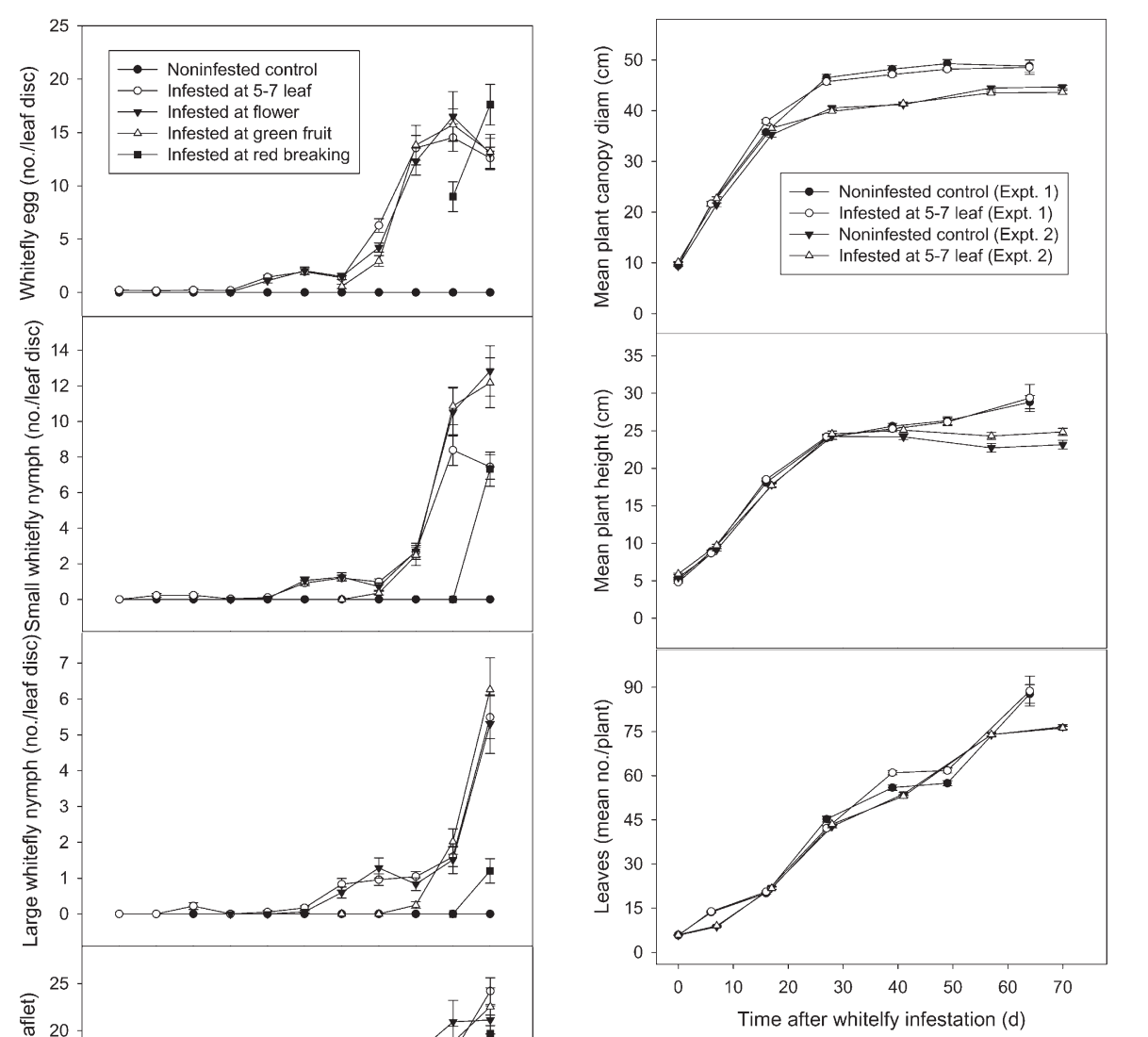

Fig. 3. Number of leaves per plant, plant height (substrate surface to canopy top), and canopy diameter (widest point) for 'Florida Lanai' tomato plants infested with sweetpotato whitefly at the five to seven true leaves of growth for Expt. 1 $[$ noninfested control $=\bullet$; five to seven true leaves (5-7 leaf) $=0]$ and for Expt. 2 [noninfested control $(2)=\nabla ; 5-7$ leaf $(2)=\triangle$. Vertical bars represent the SE of the mean; $\mathrm{n}=7$ and 10 for Expts. 1 and 2 , respectively $(1 \mathrm{~cm}=0.3937$ inch). or leaflet (adult stage) when 'Florida Lanai' tomato plants were infested at different developmental stages of plant growth: noninfested control $=\bullet$; infested at five to seven true leaves (5-7 leaf) $=\odot$; infested at flower $=\nabla$; infested at green fruit $=\triangle$; and infested at red breaking fruit $=$; ; arrows $(\uparrow)$ denote beginning of infestation interval, and counts were made every $7 \mathrm{~d}$. Leaf discs were $50 \mathrm{~mm}^{2}\left(0.0775 \mathrm{inch}^{2}\right)$ in diameter, and adult counts on leaflets were performed, nondestructively, by turning the leaflet over. Values are means of 21 and 30 leaf discs for Expts. 1 and 2, respectively, and 100 leaflets for both experiments. Vertical bars represent the SE of the mean.

for tomato seeds harvested from fruit representing early, middle, and late dehiscence from each infestation time interval were not significantly different, indicating that seed production and germination rate for this cultivar do not appear to be affected by tomato irregular ripening disorder.

Plant nutrition does not appear to play a role in the development of tomato irregular ripening in terms of how much of the fruit produced will develop the disorder. Interactions (Expt. $\times$ treatment $\times$ fruit) pertaining to internal $(F=1.06 ; \mathrm{df}=691,923$; $P<0.1759)$ and external $(F=1.06$; $\mathrm{df}=691,923 ; P<0.1479)$ tomato irregular ripening fruit ratings were not significant between experiments, thus rating data were combined (Table 2). Almost all the fruit (99\%) produced by tomato plants infested with sweetpotato whitefly at the five to seven true leaf and flower stages of plant growth $(78$ and $56 \mathrm{~d}$ of 
sweetpotato whitefly exposure, respectively) developed tomato irregular ripening with fruit exhibiting internal and external symptoms equally (Table $2)$. Plants infested at the green fruit stage $(35 \mathrm{~d}$ of sweetpotato whitefly exposure) had $79 \%$ of the fruit develop tomato irregular ripening. Surprisingly,

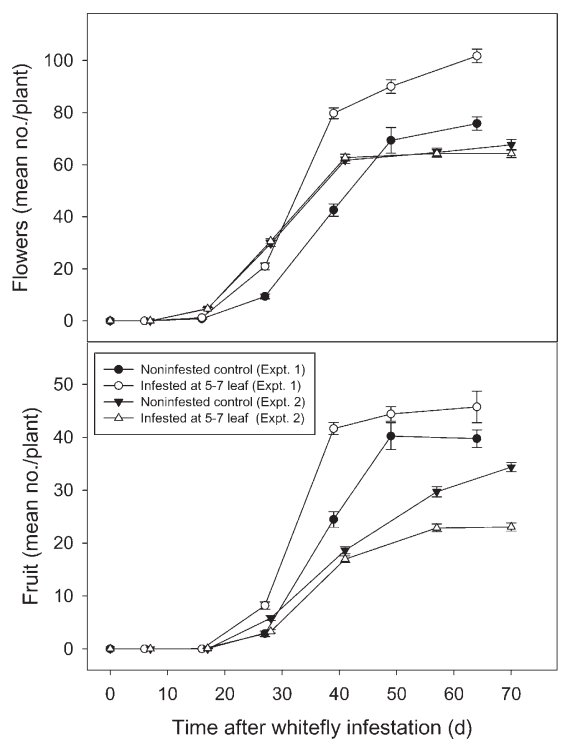

Fig. 4. Number of flowers and fruit per plant for 'Florida Lanai' tomato plants infested with sweetpotato whitefly at the five to seven true leaves of growth for Expt. 1 [non-infested control $=\bullet$; five to seven true leaves $(5-7$ leaf $)=0$ ] and for Expt. 2 [noninfested control $(2)=\nabla ; 5-7$ leaf $(2)=\triangle]$. Vertical bars represent the SE of the mean. $\mathbf{n}=7$ and 10 for Expts. 1 and 2, respectively.
$58 \%$ of fruit from plants infested at the red breaking stage (14 d of sweetpotato whitefly exposure) also developed the disorder, indicating that tomatoes may need to be protected from sweetpotato whitefly until harvest to avoid this disorder.

Schuster (2002) reported that an action threshold of 0.5 sweetpotato whitefly nymph per leaflet was needed for applying insect growth regulators to consistently yield external and internal irregular ripening ratings and marketability similar to the imidacloprid grower standard. Our data also support a low threshold of sweetpotato whitefly to induce this disorder coupled with a very short sweetpotato whitefly infestation time interval of 2 weeks immediately before harvest time. Tomatoes were infested with sweetpotato whitefly at the red breaking fruit stage for $14 \mathrm{~d}$ (until all fruit was ripe in the noninfested controls). This stage has fruit that were already ripe, fruit that were partially ripe, and fruit that were still green. Flowers were tagged at dehiscence so that fruit of the same age could be compared between treatments at harvest. It was evident that flowers tagged early had ripened before sweetpotato whitefly being added and those flowers that were tagged later and were still partially ripe or still green developed the disorder during that 14-d window.

Means of small and large nymph populations for plants infested at the

Table 2. Percentage of fruit exhibiting tomato irregular ripening (TIR) symptoms at final harvest $126 \mathrm{~d}$ after initiating treatments. Treatments consisted of 'Florida Lanai' tomato plants infested for 14 to $78 \mathrm{~d}$ or noninfested (Control, $0 \mathrm{~d}$ ) with sweetpotato whitefly at different physiological stages of plant growth (infestation interval, time infested with sweetpotato whitefly). Values are the means of Expts. 1 and 2, and symptoms of TIR were assessed by examination of the fruit surface (external fruit surface) followed by dissection of the fruit (sliced equatorially) for examination of flesh (internal fruit flesh).

\begin{tabular}{|c|c|c|c|}
\hline \multirow[b]{2}{*}{$\begin{array}{l}\text { Infestation } \\
\text { interval }\end{array}$} & \multirow{2}{*}{$\begin{array}{c}\text { Time infested } \\
\text { with sweetpotato } \\
\text { whitefly (d) }\end{array}$} & \multicolumn{2}{|c|}{ Proportion of fruit with TIR symptoms (\%) } \\
\hline & & $\begin{array}{c}\text { External fruit } \\
\text { surface }^{\mathrm{z}}\end{array}$ & $\begin{array}{l}\text { Internal fruit } \\
\text { flesh }^{\mathrm{y}}\end{array}$ \\
\hline Control & 0 & $02.8 \mathrm{~d}^{\mathrm{x}}$ & $02.3 \mathrm{~d}^{\mathrm{z}}$ \\
\hline $\begin{array}{c}\text { Five to seven } \\
\text { true leaves }\end{array}$ & 78 & 99.5 a & $99.6 \mathrm{a}$ \\
\hline Flower & 56 & 99.8 a & $99.8 \mathrm{a}$ \\
\hline Green fruit & 35 & $80.0 \mathrm{~b}$ & $79.9 \mathrm{~b}$ \\
\hline Red breaking & 14 & $58.4 \mathrm{c}$ & $58.4 \mathrm{c}$ \\
\hline
\end{tabular}

${ }^{2}$ External fruit surface characterized by incomplete reddening of the fruit exhibited by longitudinal white or yellow streaks that typically start as a star at the blossom end of the fruit with the points radiating up the fruit in a "star burst" pattern.

'Internal fruit flesh characterized by tissue white or yellow in color.

${ }^{x}$ Means in a column followed by different letters are significant at $P \leq 0.05$ according to mean separation by RyanEinot-Gabriel-Welsch multiple-range test (REGWQ).

red breaking stage were 3.8 and 0.5 nymphs per $50 \mathrm{~mm}^{2}$, respectively (Fig. 2). At $28 / 20{ }^{\circ} \mathrm{C}$ (day/night), sweetpotato whitefly eggs take between 7 to $8 \mathrm{~d}$ to hatch into small nymphs (McKenzie et al., 2005b); consequently, zero nymphs were recorded for the first sample date used to calculate the means above. In reality, nymph pressure was more like 6 to $7 \mathrm{~d}$ for small nymphs and even shorter for large nymphs, as it takes more time to mature; however, the number of nymphs would be higher during that shorter time frame [total nymph pressure of 8.8 per $50 \mathrm{~mm}^{2}$ (Fig. 2)]. In the week before harvest when almost half the fruit had already ripened, the sweetpotato whitefly caused the remaining fruit to develop tomato irregular ripening by completely shutting down the plant's ripening process.

These two experiments indicate that infestations of the sweetpotato whitefly biotype B can cause substantial losses in tomato crop production due to tomato irregular ripening at all stages of tomato plant growth. Control of sweetpotato whitefly must be maintained up to tomato crop harvest, as we found that tomato irregular ripening can be induced by this pest within 2 weeks of harvest with plants having mean total nymph counts for this time period as low as 8.8 nymphs per $50 \mathrm{~mm}^{2}$. Plant nutrition was also affected by sweetpotato whitefly biotype B with infested plants, in general, having greater foliar nutrient levels than noninfested plants. The nutrient partitioning patterns between leaves and fruit, as well as determining the effect of timing and very low whitefly infestations on the development of tomato irregular ripening disorder, will be the subject of future studies.

\section{Literature cited}

Albano, J.P. and W.B. Miller. 2003. Ferric ethylenetetraacetic acid photodegradation in a commercial fertilizer affects iron uptake in tomato. HortTechnology 13: 289-292.

Augustine, J.J., B.K. Harbaugh, and J.P. Crill. 1981. Florida Lanai: A dwarf tomato for the patio. Inst. Food Agr. Sci., Univ. Florida. Circular S-284.

Bellows, T.S., Jr., T.M. Perring, R.J. Gill, and D.H. Headrich. 1994. Description of a species of Bemisia (Homoptera:Aleyrodidae). Ann. Entomol. Soc. Amer. 76: 310-313. 
Blair, M.W., M.J. Bassett, A.M. Abouzid, E. Hiebert, J.E. Polston, R.T. McMillan, Jr., W. Graves, and M. Lamberts. 1995. Occurrence of bean golden mosaic virus in Florida. Plant Dis. 79:529-533.

Delahunt, K. and W. Stevenson. 2004. Tomato disorder: Physiological fruit problems. College Agr. Life Sci., Univ. Wisconsin, Coop. Ext. Publ. A3798.

Duffus, J.E. 1995. Whitefly transmitted yellowing viruses of the Cucurbitaceae, $\mathrm{p}$. 12-16. In: G.E. Lester and J.R. Dunlap (eds.). Cucurbitaceae. Gateway Printing, Edinburg, TX.

Frohlich, D., I. Torres-Jerez, I.D. Bedford, P.G. Markham, and J.K. Brown. 1999. A phylogeographic analysis of the Bemisia tabaci species complex based on mitochondrial DNA markers. Mol. Ecol. 8:1683-1692.

Hamon, A.B. and V. Salguero. 1987. Bemisia tabaci: Sweetpotato whitefly in Florida (Homoptera: Aleyrodidae:Aleyrodinae). Florida Dept. Agr. Consumer Services, Entomol. Circular 292.

Hanif-Khan, S., R.C. Bullock, P.J. Stoffella, C.A. Powell, J.K. Brecht, H.J. McAuslane, and R.K. Yokomi. 1997. Possible involvement of altered gibberellin metabolism in the induction of tomato irregular ripening in Dwarf cherry tomato by silverleaf whitefly. J. Plant Growth Regul. 16:245-251.

Hanif-Khan, S., R.C. Bullock, P.J. Stoffella, C.A. Powell, J.K. Brecht, H.J. McAuslane, and R.K. Yokomi. 1998. Tomato irregularripening symptom development and ripening of silverleaf whitefly-infested dwarf cherry tomatoes. J. Amer. Soc. Hort. Sci. 123:119-125.

Hochmuth, G.J., D.N. Maynard, C.S. Vavrina, W.M. Stall, T.A. Kucharek, P.A. Stansly, T.G. Taylor, S.A. Smith, and A.G. Smajstrla. 1999. Tomato production in Florida, p. 233-241. In D.N. Maynard and G.J. Hochmuth (eds.). Vegetable production guide for Florida. Univ. Florida, SP-170.

Hoelmer, K.A., L.S. Osborne, and R.K. Yokomi. 1991. Foliage disorders in Florida associated with feeding by sweetpotato whitefly, Bemisia tabaci. Fla. Entomol. 74:162-166.

Kring, J.B., D.J. Schuster, J.F. Price, and G.W. Simone. 1991. Sweetpotato whiteflyvectored geminivirus on tomato in Florida. Plant Dis. 75:1186. (Abstr.).
McAuslane, H.J. 2007. Sweetpotato whitefly B biotype of silverleaf whitefly, Bemisia tabaci (Gennadius) or Bemisia argentifolii Bellows and Perring (Insecta: Hemiptera: Alerodidae). Inst. Food Agr. Sci., Univ. Florida, Publ. EENY-129.

McCollum, T.G., P.J. Stoffella, C.A. Powell, D.J. Cantliffe, and S. Hanif-Khan. 2004. Effects of silverleaf whitefly feeding on tomato fruit ripening. Postharvest Biol. Technol. 31:183-190.

McKenzie, C.L., X.H. Sinisterra, C.A. Powell, M. Bausher, J.P. Albano, and R.G. Shatters, Jr., 2005a. Deciphering changes in plant physiological response to whitefly feeding using microarray technology. Acta Hort. 695:347-352.

McKenzie, C.L., A.A. Weathersbee, III, and G.J. Puterka. 2005b. Toxicity of sucrose octanoate to egg, nymph and adult Bemisia tabaci (Homoptera: Aleyrodidae) using a novel plant-based bioassay. J. Econ. Entomol. 98:1242-1247.

Nava-Camberos, U., D.G. Riley, and M.K. Harris. 2001. Temperature and host plant effects on development, survival, and fecundity of Bemisia argentifolii (Homoptera: Aleyrodidae). Environ. Entomol. 30:55-63.

Olson, S.M. 2004. Physiological, nutritional, and other disorders of tomato fruit. Inst. Food Agr. Sci., Univ. Florida, Publ. HS-954.

Perring, T.M., A.D. Cooper, R.J. Russell, C.A. Farrar, and T.S. Bellows, Jr. 1993. Identification of a whitefly species by genomic and behavioral studies. Science 259:74-77.

Picha, D.H. and C.B. Hall. 1981. Influences of Potassium, cultivar, and season on tomato graywall and blotchy ripening. J. Amer. Soc. Hort. Sci. 106:704-708.

Powell, C.A. and P.J. Stoffella. 1993. Influence of endosulfan sprays and aluminum mulch on sweetpotato whitefly disorders on zucchini squash and tomatoes. J. Production Agr. 6:118-121.

Powell, C.A. and P.J. Stoffella. 1995a. Susceptibility of tomato cultivars to internal and external tomato irregular ripening. HortScience 30:1307.

Powell, C.A. and P.J. Stoffella. 1995b. Culling tomatoes with external symptoms of irregular ripening is of limited benefit. HortScience 30:316-317.
Powell, C.A. and P.J. Stoffella. 1998. Control of tomato irregular ripening with imidacloprid. HortScience 33: 283-284

Schuster, D.J. 2001. Relationship of silverleaf whitefly population density to severity of irregular ripening of tomato. HortScience 36:1089-1090.

Schuster, D.J. 2002. Action threshold for applying insect growth regulators to tomato for management of irregular ripening caused by Bemisia argentifolii (Homoptera: Aleyrodidae). J. Econ. Entomol. 95:372-376.

Schuster, D.J., J.F. Price, J.B. Kring, and P.H. Everett. 1989a. Integrated management of the sweetpotato whitefly on commercial tomato. Inst. Food Agr. Sci., Univ. Florida, Res. Rpt. BRA1989-12.

Schuster, D.J., P.H. Everett, J.F. Price, and J.B. Kring. 1989b. Suppression of the sweetpotato whitefly on commercial fresh market tomatoes. Proc. Florida State Hort. Soc. 102:374-379.

Schuster, D.J., T.F. Mueller, J.B. Kring, and J.F. Price. 1990. Relationship of the sweetpotato whitefly to a new tomato fruit disorder in Florida. HortScience 25:1618-1620.

Simone, G.W., J.K. Brown, E. Hiebert, and R.E. Cullen. 1990. New geminivirus epidemic in Florida tomatoes and peppers. Phytopathology 80:1063. (Abstr.).

U.S. Environmental Protection Agency. 1997a. Method 6010B: Inductively coupled plasma-atomic emission spectrometry, Test methods for evaluating solid waste, physical/chemical methods, EPA Publication SW-846, 3rd edition, as amended by Updates I, II, IIB, III, and IIIB finalized in the Federal Register on 13 June 1997. U.S. Environmental Protection Agency, Washington, DC.

U.S. Environmental Protection Agency. 1997b. Method 3052: Microwave assisted acid digestion of siliceous and organically based matrices, Test methods for evaluating solid waste, physical/chemical methods, EPA Publication SW-846, 3rd edition, as amended by Updates I, II, IIB, III, and IIIB finalized in the Federal Register on 13 June 1997. U.S. Environmental Protection Agency, Washington, DC. 